\title{
Artelogie
}

Recherche sur les arts, le patrimoine et la littérature de l'Amérique latine

1 | 2011

Brésil, questions sur le modernisme

\section{Lima Barreto muito além dos cânones}

\section{Nádia Maria Weber Santos}

URL: https://journals.openedition.org/artelogie/8422

DOI: 10.4000/artelogie.8422

ISSN: 2115-6395

\section{Editora}

Association ESCAL

\section{Refêrencia eletrónica}

Nádia Maria Weber Santos, «Lima Barreto muito além dos cânones», Artelogie [Online], 1 | 2011, posto online no dia 01 março 2011, consultado o 07 janeiro 2022. URL: http://journals.openedition.org/ artelogie/8422 ; DOI: https://doi.org/10.4000/artelogie.8422

Este documento foi criado de forma automática no dia 7 janeiro 2022.

Association ESCAL 


\title{
Lima Barreto muito além dos
} cânones

\author{
Nádia Maria Weber Santos
}

"A literatura, portanto, fala ao historiador sobre a
história que não ocorreu, sobre as possibilidades
que não vingaram, sobre os planos que não se
concretizaram. Ela é o testemunho triste, porém
sublime, dos homens que foram vencidos pelos
fatos."
Nicolau Sevcenko, A literatura como missão
"Existe no fundo da mente de todo artista algo
como um modelo ou um tipo de arquitetura. É
algo como a paisagem de seus sonhos; o tipo de
mundo que ele gostaria de construir ou no qual
gostaria de vagar; a estranha flora e fauna de seu
próprio planeta secreto."
Chesterton, apud SACKS, Oliver, "A paisagem de
seus sonhos", Um antropólogo em marte"

1 A partir da leitura dos textos dos prefaciadores das obras completas (1956) de Lima Barreto (1881-1922), de sua biografia escrita por Francisco de Assis Barbosa e de alguns de seus escritos, discute-se o espaço da obra do escritor na literatura brasileira. Nunca adaptado ao cânone literário de sua época e local, marginalizado socialmente, alcoolista e duas vezes internado em hospital psiquiátrico, as imagens literárias construídas do Brasil pelo escritor, em suas crônicas, escritos íntimos e romances, e na sua relação com a confluente modernidade brasileira, extrapolam as nuances de sua vida comum exposta como pano de fundo e dão lugar a uma das mais ricas obras literárias-críticas da história da sociedade brasileira daquele momento.

2 É, também, através da relação da história com a literatura, que se tenta chegar mais próximo das sensibilidades, idéias e sentimentos de um outro tempo, neste caso, de um Brasil ainda jovem em termos de República, com uma vida cultural em turbulência - 
como em outros países do ocidente geográfico - conturbado socialmente e tendo cada vez mais jovens escritores que se debruçavam sobre determinadas problemáticas da nação. Os escritos de Lima, transitando por romances, sátiras, tragédias, críticas, crônicas e depoimentos, mostram o quanto sua obra ficcional é viva e mescla-se com sua vida real. Mas, também, o conjunto de sua obra transcende sua pessoalidade, porque é simbólica e sensível ao momento histórico.

3 As obras de Lima Barreto foram publicadas em edição completa de 17 volumes pela Editora Brasiliense em 1956. Os textos foram organizados e anotados sob a direção de Francisco de Assis Barbosa, com a colaboração de Antonio Houaiss e M. Cavalcanti Proença. Cada uma das obras é antecedida por um prefácio assinado pelos seguintes autores: Francisco de Assis Barbosa (volume I- Romance: Recordações do escrivão Isaías Caminha), M. Oliveira Lima (volume II - Romance: Triste fim de Policarpo Quaresma), João Ribeiro (volume III - Romance: Numa e Ninfa), Alceu Amoroso Lima, pseudônimo de Tristão de Ataíde (volume IV - Romance: Vida e morte de M.J. Gonzaga de Sá), Sérgio Buarque de Holanda (volume V - Romance: Clara dos Anjos), Lúcia Miguel Pereira (volume VI - Contos: Histórias e sonhos), Osmar Pimentel (volume VII - Sátira: Os Bruzundangas), Olívio Montenegro (volume VIII - Sátira: Coisas do reino de Jambón), Astrojildo Pereira (volume IX - Artigos: Bagatelas), Jackson de Figueiredo (volume X Artigos e crônicas: Feiras e mafuás), Antonio Houaiss (volume XI - Artigos e crônicas: Vida urbana), Agripino Grieco (volume XII - Artigos e crônicas: Marginália), M. Cavalcanti Proença (volume XIII - Crítica: Impressões de leitura), Gilberto Freyre (volume XIV - Memórias: Diário Íntimo), Eugênio Gomes (volume XV - Memórias: Cemitério dos Vivos, que inclui Diário de Hospício), Antonio Noronha dos Santos (volume XVI - Correspondência: volume I) e B. Quadros, pseudônimo de Antônio Noronha dos Santos (volume XVII - Correspondência: volume II). ${ }^{1}$

Estes prefácios, dada a importância de seus autores e de suas colaborações no âmbito da história e da cultura brasileira, servem não como uma biografia, mas como um autêntico suporte de crítica literária para a obra deste "escritor boêmio". Porém, o que vemos nestes prefácios não são posições unívocas e sim pontos de vistas que algumas vezes dão as mãos ao paradigma modernista de 1922 (e o declaram pré-modernista) e outras reconhecem, em Lima, um literato inserido no cerne das transformações que estão ocorrendo na cultura brasileira daquele período como um todo. ${ }^{2}$

Parte-se de uma indagação: como e por que as obras de Lima Barreto foram 'descobertas' e aplaudidas apenas em um período mais tardio da modernidade literária no Brasil, mais de 30 anos após sua morte ? Problemas e questões editoriais à parte, os leitores verão que este questionamento é pertinente ao contexto das letras brasileiras.

Dizemos junto com Sevcenko que os dois trabalhos - obras completas de 1956 e a biografia de 1952, vinda a público alguns anos antes da edição das obras completas, pela escrita de Francisco de Assis Barbosa, futuro organizador das obras - não só reavaliaram a posição do escritor na historia literária do país, como projetaram para o primeiro plano um período até então relativamente obscuro e que se revelaria decisivo para a compreensão do Brasil contemporâneo É de um artigo de jornal, de autoria de Nicolau Sevcenko, que retiramos a melhor análise lida até então, resumida, sobre a "descoberta" das obras e da vida literária de Lima Barreto, bem como do surgimento, naquela época tardia da modernidade brasileira, de sua biografia. Além de reproduzir a crítica de Tristão de Ataíde, um dos prefaciadores, Sevcenko, ele historiciza um pouco do processo desafiador que constituiu esta empreitada, assumindo o mesmo ponto de 
vista que temos em nossa pesquisa. Ou seja, Lima Barreto, ao produzir uma das mais raras e profundas percepções da realidade social brasileira vista de baixo para cima, julgando os poderosos pela indignação dos injustiçados, pagou um preço alto por isso naquela época, pois a elite letrada cercou a força de sua obra com uma muralha de silêncio por um longo tempo. ${ }^{3}$

7 Também é na vertente do pensamento de Monica Pimenta Velloso que inserimos o debate deste artigo, ao utilizarmos a noção de 'brasilidade modernista' como um processo multifacetado e polissêmico. Em sua obra "História \& Modernismo", a autora inicia fazendo uma diferenciação entre os termos Moderno, Modernismo e Modernidade $^{4}$, importante ao mote deste trabalho. Embora assumam um caráter fronteiriço, são diferentes em sua gênese e em sua aplicação. Iniciando por apresentar o termo moderno, "transitório por natureza", pois é aquilo que existe no momento, ela faz uma verdadeira historicização desta noção, não permitindo que nos atenhamos a épocas específicas como marcos divisórios.

8 Ao dizer "ao eleger o século XVIII como marco do moderno, corre-se o risco de desqualificar as experiências que marcaram os séculos XVI e XVII", a historiadora assume como simplificadora a idéia da historiografia do moderno que associa esse período com a figura de Baudelaire como sendo arauto verdadeiro da modernidade - porque "se perde de vista a dinâmica de um processo que já estava em curso", pois ele próprio dialogou com um corpo de tradições intelectuais que o antecederam. Mesmo assim, deve-se constatar que foi de Baudelaire o mérito de ter conferido à palavra modernité o seu sentido definitivo: "percebeu-a como mediação entre duas percepções".

Diz ainda Velloso: "A modernidade é passado/presente, integrando novidade e curiosidade à celebração do antigo. Logo, o antigo deixara de ser configurado como exemplo, modelo $e$ paradigma, para transfigurar-se na historicidade do presente. A cosmovisão de modernité ocasionou, portanto, a constituição de uma dualidade, porém uma dualidade que se definia como harmonia." 5

10 Não podendo aprofundar todas estas questões expostas acima neste momento, ressalto que a noção, trazida por Velloso, de processo, de períodos que não são estanques, é importante para localizarmos Lima Barreto (1881-1922) no cenário intelectual brasileiro. Ele foi um moderno do seu tempo... para além dos cânones... Ele encontrava em sua experiência marginal, em sua sensibilidade de escritor e, não menos importante, nas ruas do Rio de Janeiro, uma forma de expor o momento social, cultural, político e econômico pelo qual passava o Brasil. Era um momento de passagem, uma transição, que anos depois seria pensado, também, a partir de suas obras. Sua vida, marcada por sentimentos de profunda solidão e de exclusão, foi matéria prima para seus escritos, não obstante o literato tenha extrapolado estes sentimentos para dar forma a uma forte obra literária. Lima insurgiu-se contra a ordem estabelecida nos cânones literários e contra o cerceamento da liberdade na sociedade carioca que se modernizava rapidamente. É deste Lima Barreto que falaremos neste artigo.

11 Gilberto Freyre, que prefacia o Diário Íntimo, afirma que Lima ressentia-se de ser mulato, ou quase negro, como algumas vezes dizia: "Era assim um desajustado, a sofrer constante e intensamente de seu desajustamento de mulato pobre". Para ele, Lima foi obrigado, pela sua condição econômica, a ser, em grande parte, sociologicamente, um homem de cor. Por ser pobre, não teve oportunidade de transformar-se em mulato sociologicamente branco como, na mesma época, "o igualmente negróide evidente" - embora bem mais claro 
de pele do que Barreto - Machado de Assis, ou mesmo como o quase negro Juliano Moreira, "médico ilustre casado com alemã branquíssima". ${ }^{6}$

Esta impressão analítica de Freyre é corroborada por muitos críticos da época, bem como pelas próprias narrativas de Lima em várias passagens de sua obra, aliás, em muitas delas (como em seus diários, por exemplo). Neste prefácio, ainda, o sociólogo evoca a memória do autor, descendente de escravos e negros africanos, fazendo justiça: justiça intelectual. A este "homem de sensibilidade quase de moça", diz ele, faltou a certeza de possuir inteligência excepcional e mesmo de gênio. Certo de que Lima assim queria, "ser inteligente muito e muito!".

Mas, a outra impressão que se tem, ao ler sua obra, é que todos estes fatos foram, além de marcantes, matéria-prima para a literatura de ficção de Lima Barreto. Suas obras são simbólicas e exprimem sensibilidade, como já se disse. Porém, enquanto ainda vivia, elas foram duramente criticadas por ser uma 'literatura autobiográfica', onde, em cada um de seus romances, diziam os críticos, seus personagens representavam verdadeiras partes de sua personalidade, ou ainda, a imagem de seu pai - em Recordações do escrivão Isaías Caminha ou Triste fim de Policarpo Quaresma, só para citar os mais conhecidos e polêmicos na época. Seriam, também, aos olhos desses mesmos críticos, 'romancescatarses', onde o lado pessoal de sua crítica a vários setores da sociedade surgia em detrimento da 'arte de criar'.

14 Alguns críticos foram mais amenos em suas análises, muitos entendiam os dois aspectos da obra (catarse e criatividade) e outros foram radicais em tornar com valor negativo o aspecto "confessional" da obra.

Olívio Montenegro, prefaciador de Coisas do Reino de Jambon, refere que LB foi o escritor brasileiro que mais olhou a si - mesmo para escrever. "Desigual e hibrida como possa parecer sua obra, nela o traço pessoal e íntimo é o que toma mais vulto." ${ }^{8}$, segundo o crítico, Lima não foi um autor popular, em seu tempo, como exceção à regra daqueles que gritam e atingem a alma do povo. Mas, foi no romance, "o gênero mais atraente da ficção", onde seu espírito de revolta se exerceu com maior liberdade.

16 Para alguns destes, a criatividade aconteceria, somente, no âmbito da ficção, jamais podendo ter esta uma âncora na realidade. Seja uma realidade pessoal, seja a realidade coletiva, de uma nação, por exemplo.

17 Escreveu Eugênio Gomes, no prefácio da edição de 0 Cemitério dos Vivos, que em seus romances à clef, como Recordações do Escrivão Isaías Caminha, "no qual vinga asperamente as suas humilhações em contacto com os meios jornalísticos" e, Numa e Ninfa, "destinado a fixar a comédia política numa das épocas mais curiosas da vida republicana em nosso país", o humor satírico de Lima Barreto deriva para o lado pessoal, com o sacrifício da criação literária. ${ }^{9}$

o que realmente, então, teriam dito sobre seu 'romance-memória', Cemitério dos Vivos, escrito exatamente com o intuito revelado de mostrar a vida dentro dos hospícios, por onde ele passou ? Em entrevista a um jornal carioca, a qual consta em anexo nesta referida obra, Lima Barreto fala sobre a escritura deste romance e refere que sua maior ventura é a liberdade e afirma que o hospício é uma prisão como qualquer outra. ${ }^{10}$

Tomando emprestadas novamente as palavras de Monica Velloso, ao se referir a Walter Benjamin analisando Baudelaire, pode-se dizer que Lima "buscara reavivar a força da experiência, da tradição e da memória em um mundo assolado pelo acúmulo de informações, 
sensações e velocidade" ${ }^{11}$, guardado as devidas diferenças de lugar e visão de mundo de ambos. Ou seja, o contrário do que estes críticos acima diziam.

É na virada do século XIX para o XX - onde se instala com clareza a obra de L. Barreto que se situa o terceiro momento da genealogia histórica do moderno, conforme a autora, acreditando-se que caberia às artes realizar a dupla tarefa de destruição e construção - referindo-se às profundas transformações pelas quais o mundo passava nesta época. "O Modernismo abrigou o conjunto de transformações sofridas no campo das artes entre a década de 1870 e o início da Segunda Guerra, envolvendo toda a Europa e Estados Unidos. Presenciando uma crise cultural sem precedentes, o movimento criou linguagens e expressões artísticas que buscavam entender o caos social decorrente de uma mudança radical de referências e padrões civilizatórios. Segundo a autora, a crise afetava, sobretudo, a autoconfiguração dos intelectuais e dos artistas. ${ }^{12}$

21 Ainda seguindo na corrente de idéias desta historiadora, o movimento modernista, difundindo-se em muitos países do ocidente, conjugou fontes e tradições intelectuais diversas, ocorreu em contextos e temporalidades distintos, transformando-se em movimento estético e servindo para modificar o modo de pensar o mundo e ter consciência sobre ele, transformando a própria compreensão da cultura.

Pensando a partir da faceta brasileira do chamado Modernismo, deixa-se de lado a "paradigmática virada e ruptura" de 1922, para adequar-nos a esta noção de processo multifacetado e polissêmico, num país de uma diversidade cultural enorme, de influências externas variadas e de uma gama diversificada de intelectuais e escritores dignos de altas notas, nacional e internacionalmente..$^{13}$

Para a historiadora Velloso, a instauração do Modernismo compreende um longo trajeto feito de avanços e recuos, lampejos inovadores e gestos de contenção, ação laboriosa de leitura das tradições e adesões apaixonadas. "Desde a virada do século XIX, no conjunto da produção artístico-literária nacional, são claros os "sinais de modernidade". Ao questionarmos a memória canônica, a visão hierárquica das artes e dos saberes, entendendo que cada um deles forja juizos de valores específicos contribuindo de formas, também específicas, para a constituição do moderno, abriu-se novas possibilidades para pensar a vida social". ${ }^{14}$

24 Monica Velloso, no capítulo em que discute a "busca pela brasilidade modernista", finaliza-o dizendo que as vozes de Gilberto Freyre, Mário de Andrade e Carlos Drummond de Andrade, de formas distintas, ressaltaram a fraternidade, a simplicidade e a cotidianidade como valores presentes na brasilidade. E que esta visão de moderno ganhou, no Rio de Janeiro, traços marcantes e inconfundíveis. Mas, como capital, esta cidade apresentava particularidades que marcaram seu processo de modernização: existindo um abismo entre o Estado e a sociedade como um todo, as elites políticas mostraram-se incapazes de integrar as camadas mais populares. Como diz a autora, foi uma experiência de modernidade forjada pela exclusão social, onde uma espécie de pacto não escrito regia as relações: "o governo negava a participação do cidadão nos negócios públicos, em contrapartida era vetada a ingerência pública na vida doméstica" ${ }^{15}$

25 A proposta civilizatória não se fez acompanhar da extensão das práticas democráticas. Identificadas com valores da cultura européia, as elites negavam as origens mestiças da nacionalidade, reforçando-se os mecanismos de diferenciação. É neste quadro que se inserem os intelectuais boêmios. Parte expressiva do grupo tendeu a aliar-se às camadas populares, compartilhando sentimentos de rebeldia e exclusão. Afirma Velloso, que a cultura modernista no Rio é indissociável da ação do grupo de intelectuais boêmios, predominando crítica mordaz e humor, em caricaturas e crônicas, 
principalmente. Porém, não foi um grupo homogêneo e unívoco, mas todos fizeram "barulho" nos meios cariocas da crítica, da literatura e do humor. ${ }^{16}$

Olhando-se para a expressão/noção "brasilidade modernista"17, obtém-se a "deixa" para adentrar no palco da obra de Lima Barreto, no teatro de seus personagens, em sua sensibilidade literária, e pensá-la em relação a este polissêmico processo estético-cultural brasileiro. O modernismo no qual se inserem os escritos de Lima Barreto é resultante de um processo histórico em que se combinavam as mais distintas tradições, espaços, temporalidades, atores e configurações. Aqui, sua literatura deixa de ser rotulada como "pré-modernista" e passa a fazer parte deste extenso e heterogêneo processo de transformação da cultura brasileira desde os finais do século XIX, agregando novos valores culturais, sensibilidades e, por que não, ambivalências e paradoxos. Curiosamente, foi em 1922 que Lima Barreto morreu. Isto é, no mínimo, enquanto representação, paradoxal.

Poder-se-ia dizer, talvez ainda, que Lima Barreto é fora de época, ou um extemporâneo, se pensar-se em cânones; porém, ele consolidou algo que é difícil em se tratando de crítica: ele foi contemporâneo a si mesmo, ou seja, ele enxergou com lucidez (embora os cariocas de seu tempo o tenham visto muitas vezes bêbado pelas ruas e sarjetas do Rio, sem lucidez alguma aos moldes da lucidez racionalista) o momento pelo qual passavam a sociedade brasileira, a ciência médica e psiquiátrica, a cidade do Rio de Janeiro e as próprias questões literárias; escreveu sobre isto, e este é o caráter paradoxal que se encontra em sua obra. ${ }^{18}$

Seus personagens revelam, muitas vezes sangrando em veias abertas, um certo imaginário, uma certa sensibilidade sobre a nacionalidade brasileira em alguns de seus aspectos. Lima Barreto não somente juntou-se às classes mais desfavorecidas e acompanhou este movimento; ele vinha de classe popular: neto de escravos, pai tipógrafo e funcionário das Colônias de Alienados da Ilha do Governador, ele mesmo funcionário público (amanuense) do Ministério da Guerra.

A "estética da simplicidade", tão cara a alguns boêmios cariocas, pode ser encontrada na obra de Lima, em suas crônicas, contos e romances. Crítico da República Velha no Brasil, ele rompeu com o nacionalismo ufanista, escancarando a hipocrisia republicana, que mantinha os privilégios de famílias aristocráticas e dos militares. Em sua vasta obra e diversificada de 17 volumes - vasta, se considerarmos que morreu cedo, aos 41 anos cuja temática era eminentemente social e que se coadunava com esta nova estética de simplicidade, sensibilidade, fraternidade, Barreto privilegiou os pobres, os boêmios e os populares. Privilegiou porque identificou-se, no cotidiano e em suas reflexões.

30 A exclusão social do regime, o seu aspecto autoritário, corrupto e desumano, além do mal-estar intelectual, destacaram-se como os temas mais discutidos pela intelectualidade carioca, como diz Monica Velloso: "a cultura brasileira retomou em grande parte esse polo dissidente [refere-se à vertente anti-burguesa que traduz o malestar da civilização e que é a segunda vertente da tradição fundadora do modernisno]. Caricaturistas e cronistas apontaram as ambiguidades do moderno, seja em atitude de dura denúncia, seja recorrendo ao viés irônico e coloquial" ${ }^{19}$, e que é o caso de Lima Barreto.

31 Nas crônicas barretianas e em seus escritos íntimos, também se observa um panorama vivo das "tramas de culturas" que existiam no Rio de Janeiro daquela época, cidade onde ao mesmo tempo em que eram absorvidas as diversidades regionais dos outros estados, servia de polo irradiador de culturas. 

Quando se fala em "boêmios", não está se referindo à conotação literal do termo, que existe em dicionário de língua portuguesa (indivíduo despreocupado, vadio, vagabundo). Mas sim alguém que se rebelou contra os formalismos e que desmoralizou o diletantismo literário. Um crítico. E seu vício alcoólico nada tem a ver com esta figura de boêmio que alguns críticos de sua época lhe impingiram. Foi boêmio na acepção de Monica Velloso, criando uma nova sociabilidade carioca com pensadores críticos ao sistema vigente. Seria um "despreocupado", aquele que inaugurou a fase do romance moderno no Brasil ("romance de crítica social sem doutrinarismo dogmático", como disse Monteiro Lobato), que foi o pioneiro desta nova concepção de romance, e que passou a ver o homem em função da sociedade em que vive e não apenas dentro de si mesmo?

o Buarque de Holanda, no prefácio de "Clara dos Anjos", interpreta como negativo o fato de Lima ter conferido dignidade estética às mais humildes aparências. Aferrandose ao "subúrbio", o "refúgio dos infelizes", ele renuncia à respeitabilidade e a outras posições, segundo Sérgio. "Essa humanidade, despojada da 'situação normal', exilada do seu verdadeiro mundo, é que representa a matéria-prima de toda a obra de ficção de Lima Barreto."20

34 A boemia era a liberdade de imaginar um outro mundo e discutir todas as reformas necessárias para instaurá-lo. Os artistas e poetas boêmios opõem a sua trajetória aventureira e revolucionária à vida medíocre e de trabalho regular do burguês médio. A insatisfação dos boêmios era um modo de militância política. Arte, política e vida pessoal se confundiam na sustentação de um estilo pessoal de vida marcado pela diferença, já que hostilizavam as idéias de utilidade, dinheiro e sucesso a qualquer preço. É orientado por valores próprios da boêmia literária que Lima Barreto não se cansou de criticar o culto do dinheiro na civilização norte-americana e considerava absurdo qualquer pagamento por uma página de literatura. Embora o tenha feito !

parecer aos olhos de uma primeira leitura, que Lima Barreto escrevia com palavras de ressentimento - o que não é de todo uma inverdade - mas a análise de sua obra nos mostra a sutileza do escritor, nas críticas, quando por exemplo, escreve em seu Diário Íntimo em 24 de janeiro de 1908: "Fui a bordo ver a esquadria partir. Multidão. Contacto pleno com meninas aristocráticas. Na prancha, ao embarcar, a ninguém pediam convite; mas a mim pediram. Aborreci-me. Encontrei Juca Floresta. Fiquei tomando cerveja na barca e saltei. É triste não ser branco". ${ }^{21}$

Nos primeiros parágrafos da primeira versão incompleta de sua obra Clara dos Anjos, escrita em $1904^{22}$, há uma descrição pormenorizada da "cidade imaginada" do Rio de Janeiro por Lima Barreto, a cidade que tanto amava e que também ressaltou em outros vários escritos seus - narrativa esta que introduz o enredo do romance, situando os personagens principais nos inícios de 1886, os quais também se transformariam no tempo. $\mathrm{O}$ imaginário de Lima retrata a sensibilidade do autor frente às mudanças que ocorriam e que se transformavam em matéria prima para sua ficção: "A cidade do Rio de Janeiro é regularmente edificada. Não se infira daí que ela o seja conforme o estabelecido na teoria das perpendiculares e oblíquas; antes se conclua que a cidade tem se erguido acorde com a tipografia local onde se assentou e com as vicissitudes históricas que sofreu." E, logo adiante, na mesma página, diz: "Se não é regular com a estreita geometria de um agrimensor, é, entretanto, com as colinas e encostas, que a distinguem e a fazem-na formosa. Enquadra-se garridamente nelas, explicando-as e continuando-as." E aos poucos, no texto, vai entrando 
uma crítica sutil às transformações e "modernização" da cidade, fazendo aparecer sua grande sensibilidade em relação à cidade em que vivia e sua população. Veja o leitor a linda e extensa passagem do texto de Lima Barreto, na citação em anexo, que corrobora nosso pensamento. ${ }^{23}$

Novamente, a extensão da citação é necessária para se ter uma noção clara da intenção de Lima ao falar no Rio de Janeiro em sua literatura: ele sabia muito bem o que procurava; nada de "arte desinteressada", como disse Barbosa. ${ }^{24}$

Francisco de Assis Barbosa, no prefácio do primeiro volume das obras completas de Lima Barreto, ao traçar uma biografia resumida (no que diz respeito à sua entrada no mundo das Letras brasileiras), refere que bem no início de sua carreira de escritor, ao colaborar com pequenos jornais e revistas de estudantes, Lima era indeciso quanto ao rumo a tomar: escreveria ensaios ou ficção ? Seu primeiro projeto foi de escrever uma história da escravidão negra no Brasil e de sua influência na nacionalidade (e isto, Lima Barreto anuncia em seu Diário Íntimo). O prefaciador utiliza a expressão "sensibilidade ferida do adolescente de origem humilde, neto de escravos, em contato com alunos e professores brancos, ricos, semi-aristocráticos, alguns dos quais o tratam por cima, como a um ser inferior", para tentar compreender esta vontade inicial do escritor, que não se concretizou. ${ }^{25}$

Porém, falando sobre seu romance Triste Fim de Policarpo Quaresma, que foi escrito vertiginosamente, em menos de três meses - de janeiro a março de 1911 - e publicado inicialmente em folhetins do Jornal do Comércio (edição da tarde), no Rio de Janeiro, de 11 de agosto a 19 de outubro de $1911^{26}$, ao folhetim Época, Lima Barreto declarou em entrevista: “... O fim de minha vida é as letras. Eu não peço delas senão aquilo que elas me podem dar: glória! Eu sou afilhado de Nossa Senhora da Glória. Eu não quero ser deputado, não quero ser senador, não quero ser mais nada senão literato. Não peço às letras conquistas fáceis, não lhes peço gloriolas, peço-lhes coisa sólida e duradoura. E posso falar de carreira, porque se eu quisesse ter estas histórias, as teria de sobra. Eu abandonei tudo por elas; e a minha esperança é que elas me vão dar muita coisa. É o que me faz viver mergulhado nos meus desgostos, nas minhas mágoas, nos meus arrependimentos..." 27

40 A urgência de escrever que Lima possuía, por ser um literato criativo e repleto de coisas a dizer, mesclava-se com suas necessidades materiais, que de forma alguma retiraram o valor de sua obra: "O Numa e Ninfa foi escrito em vinte e cinco dias, logo que saí do hospício. Não copiei nem recopiei sequer um capitulo. Eu tinha pressa em entregá-lo, para ver se o Marinho me pagava logo, mas não foi assim e recebi o dinheiro aos poucos. Escrevi-o em outubro de 1914. 0 Marinho era diretor de A Noite."28

41 O prefaciador desta obra, (Numa e Ninfa, volume III das Obras Completas) João Ribeiro, admite que o romance é um estudo da vida social e política daquele tempo. "É realmente um dos raros livros que espelham com verossimilhança senão com fidelidade, os vícios e os costumes da sociedade política". ${ }^{29}$

Porém, nos parágrafos finais, o autor faz uma crítica severa a Lima, dizendo que não há razoável acabamento no romance, falta a "chave da abóboda", pois todos os personagens desaparecem subitamente. Assim também e, Policarpo Quaresma, o romance anterior, que é "admirável pelo contexto, mas encontramos o mesmo desfalecimento, desproporcionado na conclusão. "Todos os arabescos, toda a decoração é esplêndida, mas a arquitetura é falha." Ao final, o crítico questiona se não seria o fato de Lima estar habituado a escrever em jornais - "e o jornalismo é uma arte apressada e imperfeita que não deixa amadurecer e compor-se a congruência de obras" - o fator que o faz "escrever mal". 
Porém, admite que Barreto é um grande escritor, "dotado de observação arguta", possuidor de imaginação e estilo. ${ }^{30}$

O que para esta confluente modernidade carioca de literatos boêmios era uma "estética", aos olhos dos "letrados bem pensantes" seu estilo despojado, fluente e coloquial arruinava sua escrita. É o que também escreve Oliveira Lima no prefácio de Triste Fim de Policarpo Quaresma, volume II de suas obras completas: "É um grande livro, por consenso comum. A única pecha de que o tenho ouvido culpar, não me parece absolutamente justa. Refere-se à linguagem, ou melhor, ao estilo, julgando menos cuidado e por vezes incorreto, por ser a linguagem simples e propositalmente desataviada. Por idêntico motivo era Eça de Querós no começo tachado de escrever mal. O Senhor Lima Barreto procura felizmente não escrever bonito: antes, mil vezes antes, singelo, familiar mesmo, do que pernóstico." ${ }^{31}$

Ao final deste prefácio (que é um texto jornalístico da época, conforme nota acima), o autor diz ser Policarpo Quaresma um romance onde predomina o sentimento, no qual há um "sopro de compaixão" e uma "vibração misteriosa de piedade" que resgata qualquer defeito de composição- "da mais prometedora vocação da geração nova, espírito no qual se alia ao senso do pitoresco o senso social". Oliveira Lima termina dizendo que o Senhor Lima Barreto se contenta, sem esforços de originalidade, em "ser ele próprio." Ou seja, a crítica daquele momento, não engolira mesmo a obra de LB. ${ }^{32}$

45 Porém, são nas palavras de seu biógrafo principal e organizador das obras, que se encontra, em primeira mão, a inversão desta crítica e a idéia de intenção literária na obra de Lima. Isto nos faz perceber o quanto ele era "moderno" e o quanto ele estava no fluxo das mudanças que ocorriam na sociedade brasileira e, mais especialmente, na sociedade (letrada ou artística) carioca: "Lima Barreto, desde cedo, sabia muito bem o que procurava. Nada de arte desinteressada. Nada de artifícios verbais. Literatura, sim, mas com objetivo certo e definido, estabelecendo entre o escritor e o público um compromisso, para ajudálo a conhecer não apenas o drama íntimo de cada um, como também as competições, erros e misérias da sociedade em que vivemos. Literatura militante, como a que sempre praticaram Lima Barreto no Brasil e Eça de Queirós em Portugal, seguindo a lição de Taine e Brunetière, tratando de tudo o que pertence ao desafio de todos nós, uma vez que - justificaria o próprio escritor - "a solidariedade humana, mais do que nenhuma outra coisa, interessa o destino da humanidade." ${ }^{33}$ Lima pode ser considerado como um escritor de transição - o que lhe restituiria o rótulo de pré-modernista, como alguns críticos o dizem - , ou estava inserido no cerne do modernismo nascente ? Fiel ao modelo do romance realista e naturalista do final do século XIX, procurou entretanto desenvolvê-lo, resgatando as tradições cômicas, carnavalescas e picarescas da cultura_popular, ao mesmo tempo em que manteve uma visão neo-romântica e elegíaca da natureza, da cidade e do ser humano. Para ele, escrever tinha finalidade de criticar o mundo circundante para despertar alternativas renovadoras dos costumes e de práticas que, na sociedade, privilegiavam pessoas e grupos. Para ele, o escritor tinha uma função social. A arte, para Lima, era um fenômeno social.

No prefácio da primeira edição (1943) de sua obra "Na antevéspera", Monteiro Lobato alertava: "Escrever é gravar reaçôes psíquicas". E, logo adiante, completa: "O escritor funciona qual antena - e disso vem o valor da literatura. Por meio dela fixam-se aspectos da alma dum povo, ou pelo menos instantes da vida desse povo" ${ }^{34}$. A obra de Lima é um exemplo ainda vivo do Brasil da Velha República, sua linguagem direta e vigorosa (para não dizer sua "pena e línguas afiadas" !) toca em feridas que não se sabe se já foram cicatrizadas em nosso país, como por exemplo, ao criticar também a Academia 
Brasileira de Letras e o mundo (ou a cena !) literário daquele período. Considerava-se um homem, de vida urbana conturbada, condenado pelos literatos bem pensantes, num país onde a literatura não passava de "uma continuação do exame de português". Não é para menos que foi M. Lobato o primeiro a lhe oferecer pagamento para publicar um livro seu: Vida e Morte de M.J. Gonzaga de Sá. ${ }^{35}$

Barbosa, no prefácio já citado, escreve que "decorridos mais de quarenta anos, o tempo encarregou-se de mostrar que o romancista tinha razão." E segue dizendo que seu primeiro romance publicado, Recordações do Escrivão Isaías Caminha, marcou a carreira de Lima, e, a partir deste, seria sempre o autor de "romance de escândalo", pois os senhores da literatura, aqueles que vestiam casaca e freqüentavam a Livraria Garnier, "jamais the perdoariam a ousadia da violenta arremetida, as diatribes ferinas a certos príncipes do jornalismo e das letras, as caricaturas cruéis cobrindo de ridículo os medalhões cheios de empáfia, os mais importantes da época." 36

Lima Barreto, o mulato pobre e alcoolista, fixou, anotou, registrou, comentou e criticou todos os grandes acontecimentos da vida republicana de seu período. Como num vasto painel que se desdobra em sucessivos quadros, surgem em suas obras os episódios culminantes da insurreição anti-florianista, a campanha contra a febre amarela, a ação de Rio Branco no Itamarati, o governo Hemes da Fonseca, a participação do Brasil na primeira Guerra Mundial, o advento do feminismo, as primeiras greves operárias, a Semana de Arte Moderna, o delírio do futebol e do jogo-do-bicho. "Tudo isto se misturando com os nossos ridículos e as nossas misérias, mas também sem esquecer a grandeza e a doçura do nosso povo; a mania de ostentação, o vazio intelectual e a ganância dos políticos; em suma, toda a crise das classes dirigentes, que se agravaria de modo alarmante com a queda do Império, isto por um lado; do outro, a bondade inata do brasileiro, a coragem do funcionário público humilde que luta para educar os filhos, o milagre de sobrevivência da população pobre do subúrbio carioca, que, em meio a miséria, canta e ri." ${ }^{37}$

Não lhes parecem, leitores, algumas delas, preocupações ainda atuais em nossa sociedade brasileira contemporânea, cem anos depois ?Tendo me ocupado com algumas de suas obras na tese de doutorado ${ }^{38}$, sob o ponto de vista das representações e sensibilidades sobre a loucura em textos literários, naquele momento pude observar que mesmo tendo sofrido discriminações várias, ele soube, em sua literatura, ler e escrever a realidade, mesmo sobre a loucura, um dos fatores de exclusão social mais sério que nossa sociedade apresentava (e ainda apresenta). Mesmo sentindo-se inferiorizado no meio social e cultural que o circundava, ele cumpriu o esforço de ultrapassar tudo isto em nome da literatura. Esta, sua amante mais freqüente, ao mesmo tempo que deu a ele o que pediu, também o "sugou". Mas, mesmo depois da morte, continuou-lhe fiel, pois é do escritor que temos a lembrança, os vestígios do passado ...'A literatura ou me mata ou me dá o que eu peço dela', escrevia ele em seu Diário de Hospício... ${ }^{39}$

51 No livro de contos Histórias e sonhos, o sexto volume de suas obras completas, a prefaciadora Lúcia Miguel Pereira, faz uma comparação entre Machado de Assis e Lima Barreto, dizendo que há afinidades secretas entre eles e o que aproxima os dois escritores são as explorações em profundidade que ambos realizaram; e, por serem criadores autênticos, se não pudessem escrever ficariam mutilados, privados de seu meio de comunicação. ${ }^{40}$ Porém ela é mais uma dos críticos que se revelam avessos à profusão de "confissões" feitas em sua obra. E isto distinguiria Lima e seus escritos de Machado e sua obra, ressaltando ainda sua condição de alcoolista e desequilibrado pela 
angústia existencial e alcoólica. O que para esta crítica seria avaliado negativamente, em termos de confidências deslocadas, aos olhos de outros (incluindo a autora deste artigo) é entendido como pura sensibilidade, carregada de memória subjetiva para compreender o presente: "Quem fez nas primeiras idades uma representação da vida cheia de justiça, de respeito religioso pelos direitos dos outros, de deveres morais, de supremacia do saber, de independência de pensar e agir - tudo isto de acordo com as lições dos mestres e dos livros e choca-se com a brutalidade de nosso viver atual, não pode deixar de sofrer até o mais profundo do seu ser e ficar abalado com este choque a vida toda". ${ }^{41}$ Fazendo parte do mundo dos excluídos, os loucos sempre foram rechaçados nas sociedades. Sensível aos habitantes do hospício, onde foi internado duas vezes em sua vida, ele escreveu em Cemitério dos Vivos verdadeiro depoimento sobre a loucura, as internações psiquiátricas e, não menos importante, sobre os loucos que eram seus "colegas" de enfermaria e pátio. Há uma passagem digna de nota que o leitor lerá na nota em anexo. ${ }^{42}$

Este romance (inacabado até sua morte em 1922) é a literatura que surgiu do seu Diário de Hospício, um conjunto de notas escritas desde dentro do hospital, quando de sua última internação (dezembro 1919 a fevereiro de 1920). Tanto o diário, com seus escritos íntimos, como as páginas deste romance revelam toda a sensibilidade deste escritor em relação às práticas sociais de exclusão na sociedade carioca de então, bem como os parâmetros da Medicina psiquiátrica que "desequilibram para equilibrar". Absolutamente avesso a métodos de coerção, tanto dos policiais que o levaram em camburão até o hospício, quanto do próprio "cemitério dos vivos" (nome que deu ao hospital), em suas páginas ele faz uma crítica social a partir de sua própria experiência. Também veremos isto noconto "Como o homem chegou", em suas obras completas. ${ }^{43}$

53 Nesta obra, especialmente, as fronteiras da ficção e da realidade diluem-se na vida deste homem, atormentado em sua psique, e em seu processo criativo. Como defenderse dos 'rótulos' que ele mesmo colocava em si ? Mas as forças de sua inteligência e de sua criatividade distinguem-se no meio dos gritos da loucura. Acredita-se que existia um sentido nesta trama de sua vida. Escreveria em seu Diário de Hospício: "Não me incomodo muito com o hospício, mas o que me aborrece é essa intromissão da polícia na minha vida. De mim para mim, tenho certeza que não sou louco; mas devido ao álcool, misturado com toda a espécie de apreensões que as dificuldades de minha vida material, há seis anos, me assoberbam, de quando em quando dou sinais de loucura: deliro." ${ }^{44}$

Lima Barreto, no meio de seu texto, questiona-se sobre os meandros da loucura, sobre suas origens e ramificações. Reflete sobre si mesmo e sua relação com a sociedade em que vive e com as pessoas. Coloca a literatura em seu devido pedestal, e os médicos, a psiquiatria e o hospício - "esta sombria cidade de lunáticos" - em seus devidos lugares. Denuncia, aqui também, o sistema coercitivo de um Estado que se utiliza da Medicina, do aval da Ciência, como instrumento de intervenção política para instaurar sua ordem e controlar seus indivíduos. Ele ressalta: "É uma triste contingência, esta, de estar um homem obrigado a viver com semelhante gente. Quando me vem semelhante reflexão, eu não posso deixar de censurar a simplicidade de meus parentes, que me atiraram aqui, e a ilegalidade da polícia que os ajudou. Caído aqui, todos os médicos temem pôr logo o doente na rua. Mas seguro morreu de velho e é melhor empregar o processo da Idade Média: a reclusão." 45

Possuidor de uma psique sensível às questões humanas mais prementes e como um erudito no meio da loucura, numa reflexão aguda sobre o seu estado no hospício, escreveu, logo em seguida de sua entrada no Pavilhão: “Voltei para o pátio. Que cousa, meu Deus! Estava ali que nem um peru, no meio de muitos outros, pastoreado por um bom português, 
que tinha um ar rude, mas doce e compassivo, de camponês transmontano. Ele já me conhecia da outra vez. Chamava-me você e me deu cigarros. Da outra vez, fui para a casa-forte e ele me deu um excelente banho de ducha de chicote. Todos nós estávamos nus, as portas abertas, e eu tive muito pudor. Eu me lembrei do banho de vapor de Dostoiévski, na Casa dos Mortos. Quando baldeei, chorei; mas lembrei de Cervantes, do próprio Dostoievski, que pior deviam ter sofrido em Argel e na Sibéria. Ah! A literatura ou me mata ou me dá o que eu peço dela." 46

Ele mesmo encarrega-se de resgatar sensibilidades passadas, identificando-se a outros escritos e escritores. Traz à tona Dostoiévski, Cervantes, cada qual com sua dor, seus escritos de prisões e Dante, com suas sensibilidades estéticas, com as quais Lima comunga. Irmanam-se nas letras e nas almas. A literatura, sempre ela, é seu refúgio. Nela sente-se amparado, compreendido, protegido em sua alma. Talvez por isso ela também seja carregada de motivos pessoais. Talvez somente sendo um "louco" para isto, para compreender o âmago desta intrincada rede que se delineia na loucura. A impressão que se tem é que ele tornou-se mais lúcido no hospício, ou pelo menos aguçou sua própria capacidade de sentir e refletir sobre sua doença, sobre quem ele realmente é e o que pretendia de sua vida. Ele estava com medo de morrer, dizia que para este lugar ele não voltaria mais, "somente morto". Assim, passou a limpo suas percepções.

57 Nas páginas de Lima Barreto, encontramos a ele mesmo, mas também a brasilidade modernista em 'carne, osso e alma' e, com sua obra, aciona uma "vasta rede de representações, subjetividades, imaginários e práticas culturais no conjunto do Brasil". ${ }^{47}$

Osmar Pimentel, prefaciador de Os Bruzundangas, a sátira escrita por Lima, inicia sua crítica exatamente falando sobre o que é "fazer crítica": a crítica é sob certo aspecto, uma variante da ficção. Referindo-se a Cervantes como "personagem de mil autores, isto é, de mil críticos", ele metaforiza as liberdades que os críticos tomam diante de escritores autênticos. E revela: "como o personagem da fiç̧ão bem realizado, o bom ficcionista é também uma suma de contradições psicológicas - não fossem, um e outro, produto da mesma reflexão sobre os descaminhos e as surpresas da condição humana." Completa o parágrafo dizendo que "à semelhança de qualquer personagem literariamente vivo, o escritor será sempre, sob certo aspecto, um enigma e uma contradição". ${ }^{48}$

Lima Barreto transformou-se em vários Limas, ele é inumerável, desde o prémodernista, bêbado, mestiço, jornalista burocrata, homem de caráter e romancista, até o "raro romancista brasileiro das cidades", um "evocador amoroso da vida suburbana do Rio", "o solteirão pobre que entendia a alma feminina", "o crítico implacável da burguesia em ascensão na sociedade carioca", "o flâneur suburbano", "o boêmio sensível", entre tantos outros personagens reais do urbano e da crítica literária.

Então, se crítica é fazer uma espécie de ficção, compreendemos que fizemos e faremos sempre ficções sobre Lima Barreto e seus duplos, ou seus triplos, ou seus múltiplos. Porém, teremos certeza de algumas verdades: ele tinha uma concepção de homem e de mundo só sua, verdadeiramente e originalmente sua, assim como de seu destino na sociedade. E toda sua vida e sua obra (incluindo seus personagens) estão calcadas numa visão humanista que ele sempre carregou consigo. Fazendo parte deste polissêmico Brasil, pode-se dizer que Lima e sua obra foram trans-modernistas, atravessaram os limites do tempo e da crítica e estabeleceram-se independentes na brasilidade da Literatura Brasileira, como Atená que surgiu da cabeça de Zeus. Lima Barreto muito além dos cânones. 


\section{BIBLIOGRAFIA}

ARANTES, Marco Antonio. Loucura e alcoolismo em Lima Barreto. Dissertação de Mestrado (Ciências Sociais). Pontifícia Universidade Católica de São Paulo, 1999.

ARTIÈRES, Phillippe. Arquivar a própria vida. Estudos Históricos, Rio de Janeiro, v.11, n.21, 1998, p. 9-34.

BARBOSA, Francisco de Assis. A vida de Lima Barreto. José Olympio, RJ, 2002. [8ª edição]

BARRETO, Lima. Obras Completas. Brasiliense, São Paulo, 1956. 17v. (volume I - Romance: Recordações do escrivão Isaías Caminha; volume II - Romance: Triste fim de Policarpo Quaresma; volume III - Romance: Numa e Ninfa; volume IV - Romance: Vida e morte de M.J. Gonzaga de Sá; volume V - Romance: Clara dos Anjos; volume VI - Contos: Histórias e sonhos; volume VII Sátira: Os Bruzundangas; volume VIII - Sátira: Coisas do reino de Jambón; volume IX - Artigos: Bagatelas; volume X - Artigos e crônicas: Feiras e mafuás; volume XI - Artigos e crônicas: Vida urbana; volume XII - Artigos e crônicas: Marginália; volume XIII - Crítica: Impressões de leitura; volume XIV - Memórias: Diário Íntimo; volume XV - Memórias: Cemitério dos Vivos, que inclui Diário de Hospício; volume XVI - Correspondência: volume I; volume XVII - Correspondência: volume II)

CHARTIER, Roger. A história cultural, entre práticas e representações. Difel, Lisboa, 1988.

CHARTIER, Roger. Au bord de la falaise: l'histoire entre certitudes et inquiétude. Albin Michel, Paris, 1998.

LEENHARDT, Jacques \& JOZSA Pierre. Lire la lecture. Le Sycomore, Paris, 1982.

LEENHARDT, Jacques, JOZSA, Pierre, \& PESAVENTO, S. (orgs). Discurso histórico e narrativa literária. Unicamp, Campinas, 2000.

PESAVENTO, Sandra. Relação entre história e literatura e representação das identidades urbanas no Brasil (séculos XIX e XX). In: Anos 90 revista do PPG em História da UFRGS. Editora da Universidade/UFRGS, Porto Alegre, n.4-dezembro de 1995.

PESAVENTO, Sandra. Da cidade maravilhosa ao país das maravilhas: Lima Barreto e o 'caráter nacional'. In: Anos 90, revista PPG História UFRGS. Editora da Universidade-UFRGS, Porto Alegre, n.8, dezembro de 1997.

PESAVENTO, Sandra. Fronteiras da ficção: diálogos da história com a literatura. In: Nodari, Eunice e Pedro, Joana (orgs). História: fronteiras. XX Simpósio Nacional da ANPUH. Volume II. Humanitas/ FFLCH/USP, ANPUH, São Paulo, 1999, p.819-831.

POMIAN, Krzysztof. Histoire et fiction. Le débat, Paris, Gallimard, no 54, mars/avril, 1989.

RESENDE, Beatriz. Lima Barreto e o Rio de Janeiro em fragmentos. Editora UFRJ; Editora UNICAMP, Rio de Janeiro, 1993.

RESENDE, Beatriz. Um folhetim de Lima Barreto. O subterrâneo do Morro do Castelo. Dantes, Rio de Janeiro, 1999.

RIGOLI, Juan. Lire le délire - aliénisme, rhetórique et littérature en France, au XIX siècle. Éditions Fayard, Paris, 2001.

SANTIAGO, Silviano. Nas malhas da letra. Rocco, Rio de Janeiro, 2002. 
SANTOS, Nádia Maria Weber. Histórias de vidas ausentes - a tênue fronteira entre a saúde e a doença mental. Ed. UPF, Passo Fundo, 2005.

SANTOS, Nádia Maria Weber. Narrativas da Loucura e Histórias de Sensibilidades. Ed da UFRGS, Porto Alegre, 2008.

SEVCENKO, Nicolau. A Revolta da vacina - mentes insanas em corpos rebeldes. Editora Scipione, São Paulo, 1993.

SEVCENKO, Nicolau. Literatura como missão. Tensões sociais e criação cultural na Primeira República. SP: Brasiliense, 1983.

SEVCENKO, Nicolau. Biografia de Lima Barreto escrita em 1952 ganha novos prefácios. (Artigo online). Folha online. 04/01/2003. Acessado em: 20/11/2010. Disponível em: https:// www1.folha.uol.com.br/folha/ilustrada/critica/ult569u1123.shtml

VELLOSO, Monica Pimenta. História \& Modernismo. Autêntica, Belo Horizonte, 2010.

\section{NOTAS}

1. A partir de agora, as citações feitas destes prefácios aparecerão em notas na forma [Prefácio, vol. yy, p. zz], por questão de simplificação. As referências feitas aos escritos do próprio Lima Barreto, também referentes às obras completas, aparecerão no formato [Obras completas, v. yy, p. zz]. A obra completa de Lima Barreto tem sua referência completa ao final, na bibliografia. Os originais e manuscritos do escritor encontram-se, atualmente, na Biblioteca Nacional do Rio de Janeiro, já catalogados em coleção, diferentemente de como se encontravam na época da escrita destes prefácios, conforme nota prévia de Gilberto Freyre, prefaciador do volume XIV (Diário Íntimo).

2. Tristão de Ataíde, o prefaciador do volume IV (Vida e morte de M. J. Gonzaga de Sá), romance que apareceu pela primeira vez em 1919, ressalta que Lima ficou fora e acima das grandes lutas modernistas - pela obra e pela sua morte em 1922. Seu romance surgiu antes do momento de ruptura, antes da "revolução modernista", como ele diz, onde se dividiria o campo literário em dois partidos, os novos e os velhos. Observa-se que Ataíde é ainda partidário desta dicotomia, que será mais adiante discutida neste artigo. Importa aqui observar-se que mesmo ele já reconhecia que Lima Barreto e sua obra possuíam características de independência total, dos grupos, dos manifestos, das polêmicas de escola. Não pertenciam nem aos Novos e nem aos Velhos. "E se tivesse que tomar partido, seria fatalmente contra passadistas e futuristas conjuntamente". Não porque tinha orgulho e desdém. Mas porque, de dentro de sua irresistível vocação literária, vinha uma paixão pela verdade, uma despreocupação de si mesmo, a ternura pelo sofrimento alheio e pelo próprio e uma consciência nítida das vaidades dos senhores da vida e do mundo. [Prefácio, vol. IV, p. 10]

3. Este artigo jornalístico surgiu como comentário à reedição da biografia de Lima Barreto, em 2002, pela editora original José Olympio (RJ), escrita por Francisco de Assis Barbosa em 1952. Sevcenko, Nicolau. Biografia de Lima Barreto escrita em 1952 ganha novos prefácios. (Artigo online). Folha online. 04/01/2003. Acessado em: 20/11/2010. Disponível em: https:// www1.folha.uol.com.br/folha/ilustrada/critica/ult569u1123.shtml "Não resisto a reproduzir o juízo ponderado e agudo com que ela foi recebida pelo crítico Tristão de Ataíde (1893-1983). 'Foi destacada como a melhor biografia de um escritor brasileiro já publicada em nossa língua. Foi escrita com um cuidado, uma objetividade, uma paciência, uma elegância de estilo, um critério de relação documental e acima de tudo com um amor, sem desvario, que realmente fazem dessa biografia qualquer coisa à altura do biografado. Creio que basta dizer isso para dizer tudo. Temos 
nela um modelo e uma lição, de como a verdade e a beleza, quando se entrelaçam, não há quem lhes resista. m meio à sua vida atribulada de redator-chefe da lendária 'Última Hora' de Samuel Wainer, Barbosa levou cerca de seis anos para compor esse trabalho. Em sua carreira no jornalismo, passou também, entre outros, pelo 'Correio da Manhã', 'Diário Carioca' e Folha. Como ele mesmo relata no prefácio à primeira edição, tudo começou quando o editor Zélio Valverde o encarregou, em 1946, de organizar as obras completas de Lima Barreto. Ele entrou em contato com a família e recebeu uma massa de documentos, literários e pessoais, zelosamente guardados pela irmã do escritor, dona Evangelina, no guarda-louças de sua casa. O projeto da edição das obras naufragou, então ele decidiu ir adiante com a biografia. Na sua modesta avaliação, Barbosa considerou a biografia como 'uma singela narrativa literária'. Mas o fato é que o livro teve um extraordinário impacto no momento em que veio a público, em 1952, em meio ao processo de redemocratização da vida brasileira, pós-guerra e pós-Vargas. Na seqüência, o historiador Caio Prado Jr. (1907-1990), para quem Lima Barreto era 'o maior e mais brasileiro dos nossos romancistas', sendo então o editor da Brasiliense, resolveu retomar o projeto da publicação das suas obras completas. Para comandar a iniciativa encarregou Barbosa, o qual se acercou de Manoel Cavalcanti Proença e Antônio Houaiss para enfrentar o desafio.A publicação, em 1956, das 'Obras de Lima Barreto', em 17 volumes, todos prefaciados pela fina flor da crítica e da intelectualidade, juntamente com a biografia, são um marco da cultura brasileira na segunda metade do século 20. Inspirados nessas fontes prodigiosas, toda uma nova geração de pesquisadores as tomariam como material estratégico para estudar a consolidação do regime e da sociedade republicana. A biografia interagia às maravilhas com as obras completas, na medida em que os escritos de Lima Barreto têm um caráter fortemente confessional, e Barbosa os articulou com as sucessivas fases da vida do escritor, urdindo numa trama habilidosa as vicissitudes dramáticas da sua existência, uma densa imaginação crítica e literária e as dores de gestação do Brasil moderno. Por sua origem humilde e sua sensibilidade aguçada, Lima Barreto produziu uma das mais raras e profundas percepções da realidade social brasileira vista de baixo para cima, julgando os poderosos pela indignação dos injustiçados. Pagou um preço alto por isso. A elite letrada cercou a força de sua obra com uma muralha de silêncio por um longo tempo. Foi esse muro que Barbosa pôs por terra, revelando os tesouros que ele ocultava." Leitura obrigatória em tempos de virada. Sevcenko, Folha online, 2003. Desculpem os leitores pela extensão da citação, mas somente na íntegra ela faz jus à beleza e profundidade de tratamento que Lima e sua obra mereceram por parte deste intelectual/historiador brasileiro contemporâneo.

4. VELLOSO, Monica Pimenta. História e Modernismo, pp. 11-38.

5. VELLOSO, Monica Pimenta. História e Modernismo, p.16.

6. Prefácio, vol. XIV, p. 14.

7. "Faltou-lhe essa certeza. Faltou-lhe o estímulo - talvez devesse dizer a justiça: justiça social de uma crítica esclarecida que prestigiasse nele o intelectual, autor desde a mocidade de livros que hoje o situam entre os romancistas mais significativos do Brasil. Sob o calor do prestígio intelectual, compensador de deficiências de prestígio social, é possível que seu desajustamento tivesse sido atenuado, adoçado e talvez contido ; e não chegado, como chegou, a extremos às vezes trágicos. Ele foi uma espécie de personagem de romance russo, desgarrado nos trópicos; $\mathrm{e}$ para quem só a natureza bruta destas terras de muito sol e muita côr crua, foi algumas vezes angelicamente azul: toda azul. Como na manhã de fevereiro que recorda numa de suas notas de 1905: azul diáfano. Tudo azul...o rolar das carroças é azul, os bondes azuis, as casas azuis. Tudo azul." Prefácio, vol. XV, p. 15/16.

8. Prefácio, vol. VIII, p.9.

9. Prefácio, vol. XV, p.21.

10. “...mas afinal, a maior, senão a única ventura, consiste na liberdade ; o Hospício é uma prisão como outra qualquer, com grades e guardas severos que mal nos permitem chegar à janela. Para mim, porém, tem sido útil a estadia nos domínios do senhor Juliano Moreira. Tenho coligido 
observações interessantíssimas para escrever um livro sobre a vida interna dos hospitais de loucos. Leia o Cemitério dos Vivos. Nestas páginas contarei, com fartura de pormenores, as cenas mais jocosas e as mais dolorosas que se passam dentro destas paredes inexpugnáveis. Tenho visto cousas interessantíssimas." Obras completas, vol. XVI, "Uma entrevista", p. 257. É interessante ressaltar que Lima Barreto simpatizava com Juliano Moreira, referindo-se a ele mais de uma vez no Diário do Hospício. Seria por que este também era 'quase negro' como ele ? Há uma passagem em que ele conta que o diretor do hospício [Juliano Moreira] foi ver uma algazarra que acontecia, por conta de um paciente ter subido no telhado. LB fez um comentário a este médico sobre tal doente e 'o diretor nada disse ; mas foi preciso ele vencer, com sua doçura, a sua paciência e a simplicidade de sua alma, a indelicadeza desse seu hospitalizado. Hei de falar mais longamente sobre ele, que é uma interessante figura que conheci.' [Obras completas, vol. XV, p. 85

11. VELLOSO, Monica Pimenta. História e Modernismo, p. 17.

12. "Se eles se sentiam estimulados a forjar uma nova consciência social e estética, essa liberação se dava em um clima de forte tensão histórica. O poder imaginativo conjugava-se à consciência da contingência, vivenciada como catástrofe gerando a sensação de desorientação e pesadelo." (...) "A imaginação literária e artística rebelara-se contra a ordem científico-burguesa, ocasionando um enriquecimento da percepção do mundo social que deixava de ser visto como algo exterior e consensual." VELLOSO, Monica Pimenta. História e Modernismo, p. 19-20.

13. "Foi de fundamental importância no processo de releitura do modernismo brasileiro a geração de literatos das décadas 1970/1970, incluindo Luis Costa Lima, Alfredo Bosi e Silviano Santiago. Enfatizando a diversidade da cultura brasileira (universal/particular, cosmopolitismo/ localismo, vanguardas/tradições) esses autores contribuíram para o entendimento da temporalidade múltipla que marcava a brasilidade." IN: VELLOSO, Monica Pimenta. História e Modernismo p. 26.

14. VELLOSO, Monica Pimenta. História e Modernismo,p. 89.

15. Neste momento, a autora remete à obra do historiador José Murilo de Carvalho, que examina com propriedade esta questão do caráter excludente da modernidade. Veja principalmente: Carvalho, José Murilo. Os bestializados e a República que não foi. São Paulo: Cia das Letras, 1987. VELLOSO, Monica Pimenta. História e Modernismo,p. 79.

16. "Foi uma relação ambígua marcada pela adoção eufórica de valores, crítica virulenta e humor. Através de suas crônicas e caricaturas, o grupo captou o espírito das mudanças trazido pelos tempos modernos. Lima Barreto, Bastos Tigre, Emilio de Meneses e José do Patrocínio Filho e os caricaturistas de maior projeção no momento, como Raul Pederneiras, Kalixto e J.Carlos, compuseram um grupo que, durante três décadas (virada do século XIX até finais de 1920) atuou em torno de revistas. Mas foi a D. Quixote (1917-1927), dirigida por Bastos Tigre, que funcionou como verdadeiro porta-voz e lugar de memória do grupo. Nessas publicações pode-se encontrar uma narrativa sobre a nacionalidade que se contrapõe à vertente oficial produzida pelos intelectuais do Instituto Histórico e Geográfico Brasileiro e pelo Museu Histórico Nacional. Também as expressões artísticas produzidas na Academia Brasileira de Letras e no Museu de Belas-Artes foram alvo de paródias." IN: VELLOSO, Monica Pimenta. História e Modernismo,p. 77.

17. Ver esta discussão a partir da página 39 da obra citada de Monica Pimenta Velloso (2010).

18. Talvez fosse melhor dizer "caráter dialético", o que pressupõe uma síntese ao invés de uma contradição nos termos. Pois a obra de Lima Barreto transformou o seu "estar à margem" em uma verdadeira escrita crítica e "militante" daquele período. Embora sucumbindo ao alcoolismo, sua literatura revela o Brasil e mudou sua vida. Deu-lhe a "glória" que ele tanto queria.

19. VELLOSO, Monica Pimenta. História e Modernismo,p. 83.

20. Prefácio, vol.v, p. 17.

21. Obras Completas, vol. XIV, p.130.Lima Barreto está aqui se referindo à esquadra americana de navios Lloyd, atracados no porto da cidade do Rio, em janeiro de 1908, e que trazia uma tripulação de dezesseis mil homens, de variadas nacionalidades (franceses, portugueses, italianos, 
turcos e alemães), bem como negros e mulatos, "alguns destes bem postos e fortes". Ele ganhou um convite para a visita, na secretaria de Guerra onde trabalhava, mas mesmo assim, seus sentimentos de inferioridade moral lhe tomaram conta. Há no trecho anterior desta anotação de seu Diário Íntimo uma descrição de sensibilidade e beleza ao falar sobre os traços humanos que ele tinha visto a bordo ; era seu imaginário sobre a diferença nacional/estrangeiro que se destaca aqui: "Observei fisionomias. Algumas lindas; nunca vi nas mais lindas mulheres brancas daqui o tom doce de uma fisionomia de marinheiro que me caiu nos olhos. Entre nós, as fisionomias são mais secas, contraídas, cheias de fogo, mas não têm a limpidez dessas fisionomias pré-rafaelistas. Há alguma coisa de primitivo nelas, de um primitivo sem selvageria, um sentimento de além, do desconhecido, visto pro anjos delicados. Os selvagens são sempre graves ; nós somos sempre graves, quando não, uns abandonados às contrações sagradas do 'purismo"”. [Obras completas, vol. XIV, p. 129]

22. A versão completa do romance [Obras completas, vol. V] será escrita pelo autor em 1919/ início de 1920, terá publicação póstuma e será completamente diferente desta anterior. Essa versão incompleta citada aqui se encontra ao final do volume XIV das Obras Completas (Diário Íntimo), pois os organizadores acharam por bem colocar neste volume os variados escritos avulsos, papéis soltos, "esquemas de romances frustrados, primeiras tentativas de ficcionistas, ainda em plena juventude, seguidos às vezes de capítulos inteiros, talvez completos, ao lado de outros apenas esboçados." [Prefácio, vol. XIV, p 20]

23. "Surpreendia pela fereza das lavras de Minas, que fizeram dela seu entreposto de exportação, a velha São Sebastião aterrou depressa alguns brejos ; e todo e qualquer material foi-lhe útil para tal fim. A população, preguiçosa de subir de novo os morros, construiu sobre o solo de cisco, e o rei Dom João veio descobrir praias e arredores cheios de encantos, cuja existência ela ingenuamente ignorava. Uma coisa compensou a outra , logo que a Corte quis se firmar... (...)Quem observa uma carta do Rio e tem de sua antiga topografia modestas notícias, define plenamente as preguiçosas sinuosidades das suas ruas e as imprevistas dilatações que elas oferecem. Ali, uma ponta de montanha empurrou-as ; aqui, um alagadiço dividiu-as em duas azinhagas simétricas, deixando-o intacto, à espera de um lento aterro. Na fisionomia das casas estereotipam-se as cousas de nossa história. Um observador amoroso e perspicaz não precisa ler ao alto a data, entre os ornatos de estuque para saber quando uma delas foi edificada. Esse casarão de dois andares, quês e vê na Rua do Sabão ou da Alfândega, é dos primeiros quinze anos da Independência. Vêde-lhe a segurança afetada ; a força demasiada das paredes ; a valentia dos alicerces que se adivinha... Quem o fez sabia das lutas do Primeiro Reinado, vinha seguro de possuir uma terra sua para viver a vida eterna da descendência. $O$ tráfico de escravos imprimiu ao Valongo e aos morros da Saúde alguma coisa de cubata africana, e a tristeza do cais dos Mineiros é saudade das ricas faluas que não chegam mais de Inhomirim e da Estrela, pejadas de mercadorias. 0 bonde, porém, perturbou essa metódica superposição de camadas. Hoje, o geólogo da cidade atormenta-se com o aspecto transtornado dos bairros. Não há mais terrenos paralelos ; as estratificações inclinam-se ; os depósitos baralham-se ; e a divisão da riqueza e as novas instituições sociais ajudam o bonde neste trabalho plutônico. No entanto, este veículo alastra a cidade ; cria nas pontas de seus trilhos núcleos de condensação urbana. Onde ele chega, desenha-se uma venda, surge um botequim, um quiosque; em torno, edificam-se casebres. Ondulações concêntricas a esse núcleo encontram as de outro próximo, dando nascimento a uma travessa mal povoada, tristonha, esquecida das autoridades municipais, e que vive anarquizadamente, fora de toda a espécie de legislação, a poucas centenas de metros de outras, apertadas num cinto de posturas. (...) A população que as povoa é hetereoclítica. Na generalidade, operários e pequenos empregados ; mas se algum descuidado se aventurava por uma dessas travessas adentro, surpreender-se-á sem razão ao cruzar com algum elegante da Rua do Ouvidor. Cavalheiros de extraordinária exuberância amorosa e de apoucados rendimentos resolvem o problema de sua natureza gastando com a família o mínimo, num desses corredores, e o máximo nos alfaiates e 
aperitivos platônicos com as cocottes [grifo do autor] nas confeitarias." Obras completas, vol. XIV, pp. 221-223; os grifos em itálico são meus.

24. Sérgio Buarque de Holanda, em seu prefácio desta obra (volume V, Clara dos Anjos), arrasa o romancista e suas obras. Texto jornalístico escrito em partes, em janeiro de 1949 para o Diário de Notícias, nele Sérgio revela sua opinião de crítico que não vê em Lima Barreto o gênio que o diziam ser, sobre-exaltando o valor de seus romances. Recusa-se a compará-lo com Machado de Assis. "A obra deste escritor é em grande parte uma confissão mal escondida, confissão de amarguras íntimas, de ressentimentos, de malogros pessoais, que nos seus melhores momentos soube transfigurar em arte. É essa espécie de refundição artística o que realmente importa ou importa antes do mais no estudo de tal obra, o que de fato vai valorizar as idéias nela expressas ou a crítica social onde apareça." Continua dizendo que os valores estéticos não devem ser desdenhados em benefício de outros valores. E ressalta que em Clara dos Anjos a refundição estética não se fez de modo pleno, pois "os problemas íntimos que o autor viveu intensamente e procurou muitas vezes resolver através da criação literária, não foram integralmente absorvidos e nela ainda perduram em carne e osso como corpo estranho." [Prefácio, vol. V, p. 10]

25. Prefácio, vol. 1, p. 11.

26. Sua edição integral, como romance, apareceu somente em 25 de fevereiro de 1916, pela Tipografia "Revista dos Tribunais" e foi bancada financeiramente por ele mesmo, ou melhor, pelos empréstimos que fez.

27. Obras completas, v. XIV, Nota do editor à p. 183.

28. Obras completas, v. XIV, p. 182.

29. Prefácio, vol. III, p.10.

30. Prefácio, vol. III, p. 12. O texto deste prefácio foi publicado pela primeira vez no 0 Imparcial, periódico do Rio de Janeiro, em 7 de maio de 1917 e foi conservado para ser o prefácio à obra, nas obras completas.

31. Prefácio, vol II, p.10. O texto deste prefácio também apareceu antes da edição das Obras Completas, pela primeira vez, em novembro de 1916, no Estado de São Paulo, quando da primeira publicação do romance (final de 1915), única edição deste enquanto Lima foi vivo. É importante ressaltar que estas críticas jornalísticas foram lidas por Lima Barreto, causando muitas vezes furor no escritor, outras vezes servindo de alento às suas tão maltratadas noções a respeito de si mesmo.

32. Prefácio, vol. II, p. 13 - os grifos são meus.

33. Prefácio, vol. I, pp.13-14.

34. Lobato, Monteiro. Na antevéspera. Vol. VI. Obras completas - Primeira série, Literatura Geral, 13v., 2 $2^{\mathrm{a}}$ edição, editora Brasiliense Limitada, São Paulo:, 1948.

35. Ver Barbosa, A vida de Lima Barreto, pp. 281-293.

36. Prefácio, vol. I, p.14.

37. Prefácio, vol. I, p.14.

38. Tendo como tema a loucura, como objeto textos literários e como problema a questão da sensibilidade, a realização da tese de doutorado envolveu um exercício interdisciplinar, e teve o intuito de perceber a forma pela qual a literatura, e mais especificamente os escritos de si - ou escritos auto-referenciais - são reveladores de sensibilidades sobre a loucura. Com isto, resgatou-se um pouco da História da Psiquiatria no Brasil sob um outro ponto de vista: o do próprio paciente. Foram analisados três conjuntos de textos - romance, diário e cartas - que versam sobre loucura e internações em hospícios. Revisitando a história da psiquiatria brasileira nas primeiras três décadas do século XX e cruzando com a vida e obra de três autores e de personagens da ficção, em que alguns escrevem seus textos durante hospitalização em manicômio, descortinaram-se nuanças na sensibilidade fina destes escritores relativa à noção de loucura que imperava. Estes textos, fontes primárias da pesquisa, foram os seguintes: o romance simbolista de Rocha Pombo No Hospício, publicado em 1905, no Rio de Janeiro ; o Diário do Hospício de Lima Barreto, inserido na 
edição de sua obra (romance) inacabada Cemitério dos Vivos, que relata suas memórias e reflexões durante uma internação em hospício, Hospício Nacional de Alienados do Rio de Janeiro, em janeiro e fevereiro de 1920 ; e as doze cartas de TR (iniciais), um paciente internado no Hospital Psiquiátrico São Pedro de Porto Alegre/RS, em 1937, às quais se denominou Cartas de Hospício. Esta tese foi publicada na obra: Santos, Nádia Maria Weber. Narrativas da Loucura e Histórias de Sensibilidades. Ed da UFRGS, Porto Alegre, 2008.

39. Obras completas, vol. XV, p. 35.

40. Prefácio, vol. VI, p.10.. Lima Barreto repudiou Machado de Assis e sua obra em algumas críticas e cartas. Veremos estas cartas em outro momento, em outro trabalho.

41. Obras completas, vol. IX, p. 116.

42. “Apesar de não demonstrar vestígio algum de loucura, nem mesmo a alcoólica ou tóxica, M. era veterano no hospício e me informou muito sobre os loucos, suas manias, seus antecedentes. 0 meu mergulho naquele mundo estranho foi logo profundo, naqueles quatro dias que nele passei. Vista assim de longe, a noção do horror que se tem da loucura não parte da verdadeira causa. 0 que todos julgam, é que a cousa pior de uma manicômio é o ruído, são os desatinos dos loucos, o delirar em voz alta. É um engano. Perto do louco, quem os observa bem, cuidadosamente, e une cada observação a outra, as associa num quadro geral, o horror misteriosos da loucura é o silêncio, são as atitudes, as manias mudas dos doidos.Há indivíduos que se condenam a um mutismo absoluto, que não conversam com ninguém, não dizem palavra anos e anos. Destes, uns vivem de um lado para outro, outros deitados ; ainda outros fazem gestos, e certos outros prorrompem em berreiros.Alguns, a sua doença atacou-os no aparelho de emissão da palavra. Havia um, mas na outra secção, velho e dizem que de família importante, que falava de onde em onde, mas logo perdia o jeito e emudecia. Tinha delírios terríveis. Corria que em estado de loucura matara uma irmã, na fazenda paterna, com mão-de-pilão." IN: Obras completas, vol. XV, p. 184.

43. Ver análise aprofundada deste Diário de Hospício e do romance Cemitério dos Vivos em Santos, Nádia Maria Weber. Narrativas da Loucura e História de Sensibilidades, 2008.

44. Obras completas, vol. XV, p. 33.

45. Obras completas, vol. XV, p. 72.

46. Obras completas, vol.XV, p.35.

47. VELLOSO, Monica Pimenta. História e Modernismo, p. 26.

48. Prefácio, vol. VII, p. 9.

\section{RESUMOS}

A partir da leitura dos textos dos prefaciadores das obras completas (1956) de Afonso Henriques de Lima Barreto (Lima Barreto ou LB), de sua biografia escrita por Francisco de Assis Barbosa (de 1952) e de alguns de seus escritos, discute-se o espaço da obra do escritor na literatura brasileira. Nunca adaptado ao cânone literário de sua época e local, marginalizado socialmente, alcoolista e duas vezes internado em hospital psiquiátrico, as imagens literárias construídas do Brasil pelo escritor, em suas crônicas, escritos íntimos e romances, e na sua relação com a confluente modernidade brasileira, extrapolam as nuances de sua vida comum exposta como pano de fundo e dão lugar a uma das mais ricas obras literário-críticas da história da sociedade brasileira daquele momento. 
A partir de la lecture des préfaces de l'œuvre complète (1956) de Afonso Henriques de Lima Barreto (LB), de sa biographie écrite para Francisco de Assis Barbosa et de quelques-uns de ses écrits, nous discuterons sur l'espace que l'écrivain et son œuvre ont dans la littérature brésilienne. Il n'a jamais été encadré dans le canon littéraire de son époque et de son lieu; Il fut marginalisé socialement, ivrogne et Il a eu deux internations psychiatriques. Pour cette raison les imagens littéraires qu'il a construit dans son œuvre et le rapport qu'il a eu avec le modernisme extrapolent les nuances de sa vie ordinaire, qui sont exposées en arrière-plan, et laisse la place à l'un des plus riches œuvres littéraires-critique de l'histoire de la société brésilienne à cette époque-là.

\section{ÍNDICE}

Palavras-chave: Barreto (Lima), modernidade, prefácios, literatura brasileira, brasilidade modernista, História e Literatura

\section{AUTOR}

\section{NÁDIA MARIA WEBER SANTOS}

Doutora em História; UNILASALLE/Canoas - Médica-psiquiatra, Doutora em História pela UFRGS, Professora do Mestrado Profissional em Memória Social e Bens Culturais do Centro Universitário UNILASALLE - Canoas/RS. Autora dos livros: Histórias de vidas ausentes - a tênue fronteira entre a saúde e a doença mental (Ed. UPF, 01 mars 2011 